\title{
STRATEGI PEMBELAJARAN BERBASIS MASALAH UNTUK MENINGKATKAN PEROLEHAN BELAJAR MATA KULIAH PPKn ANGKATAN 2018 UNIPA SURABAYA
}

\author{
I Wayan Arsana \\ Universitas PGRI Adi Buana Surabaya \\ Email: canangarsana60@gmail.com
}

\begin{abstract}
Abstrak
Proses pembelajaran pada program studi PPKn mengahadapi banyak persoalan, berdasarkan pengamatan secara terbatas mahasiswa cenderug pasif kurang menekankan aspek penalaran sehingga menyebabkan rendahnya minat belajar mahasiswa. Temuan mengenai aktivitas belajar mahasiswa PPKn angkatan 2018 pada siklus I menunjukkan aktivitas pembelajaran seperti: mendengarkan penjelasan dosen, menjawab pertanyaan dosen, aktivitas mahasiswa selama diskusi, mendengarkan sajian presentasi, laporan kelompok, sikap dalam berdiskusi termasuk katagori baik. sedangkan mengemukakan pendapat, bekerja sama, mendengarkan penjelasan dosen, bertanya kepada dosen termasuk katagori cukup. mengajukan pertanyaan maupun sanggahan termasuk kata gori kurang. Pada siklus II aktivitas pembelajaran seperti aktivitas diskusi dan sikap dalam berdiskusi termasuk katagori sangat baik, sedangkan mendengarkan penjelasan dosenbertanya kepada dosen menjawab pertanyaan dosen, mendengarkan sajian presentasi, mengajukan pertanyaan dan sanggahan serta pembuatan laporan kelompok termasuk dalam katagori baik, Sedangkan bekerja sama, mengemukakan pendapat termasuk katagori cukup. Mengenai perolehan belajar siklus I menunjukkan dari 29 orang mahasiswa, hanya 20 mahasiswa atau sebesar 69\% mencapai ketuntasan belajar sedangkan 9 orang siswa atau sebesar $31 \%$ belum mencapai ketuntasan belajar, sedangkan pada siklus II dari 29 mahasiswa sebayak 26 orang atau sebesar 89,7\% mencapai ketuntasan belajar, sedangkan 3 orang mahasiswa atau sebesar 10,3\% belum mencapai ketuntasan belajar.
\end{abstract}

Kata Kunci: Strategi pembelajaran berbasis masalah, aktivitas belajar dan perolehan belajar.

\begin{abstract}
The learning process in the PPKn study program faces many problems, based on the limited observation of passive students, they tend to emphasize the aspect of reasoning so that it causes low student interest in learning. The findings regarding the learning activities of students in the 2018 PPKn cycle showed learning activities such as: listening to lecturers' explanations, answering lecturer questions, student activities during discussions, listening to presentation presentations, group reports, attitudes in discussions including good categories. while expressing opinions, working together, listening to lecturers' explanations, asking lecturers including enough categories. ask questions and rebuttal including the word gori less. In cycle II learning activities such as discussion activities and attitudes in discussions are very good, while listening to lecturers 'explanations ask lecturers to answer lecturers' questions, listen to presentation presentations, ask questions and rebuttal and make group reports included in good categories, while working together, expressing opinion including enough categories. Regarding the acquisition of learning cycle I showed that of 29 students, only 20 students or 69\% achieved mastery learning while 9 students or $31 \%$ had not achieved mastery learning, whereas in cycle II of 29 students were 26 people or as much as $89.7 \%$ achieved mastery learning, while 3 students or $10.3 \%$ had not achieved mastery learning.
\end{abstract}

Keywords: Problem Based Learning Strategy, Learning Activities and Learning Acquisition. 


\section{PENDAHULUAN}

Memasuki abad 21 perkembangan ilmu pengetahuan dan teknologi utamanya pada bidang teknologi komunikasi di abad belajar ini demikian pesat, mengakibatkan terjadinya perubahan pada setiap aspek kehidupan. Demikian juga pada bidang pendidikan dan pembelajaran terjadi perubahan paradigma dari pembelajaran yang berpusat pada pembelajar menjadi pembelajaran yang berpusat pada pebelajar. Perkembangan ini mengakibatkan adanya perubahan peran dosen dalam pembelajaran yakni sebagai sumber pengetahuan berubah menjadi fasilitator, motivator, konsultan, pembimbing, dan mitra belajar.

Menurut AECT (1986) menyatakan pembelajaran merupakan proses di mana lingkungan seseorang secara sengaja dikelola sehingga memungkinkan pebelajar ikut serta dalam tingkah laku tertentu dalam kondisikondisi khusus atau menghasilkan respon terhadap situasi tertentu. Mengacu dari definisi tersebut bahwa dalam proses pembelajaran di dalamnya terkandung tiga kegiatan yakni memilih, menetapkan dan mengembangkan metode atau strategi untuk mencapai perolehan belajar yang diinginkan. Menyadari pembelajaran merupakan kegiatan inti dari proses pendidikan maka pembelajar seharusnya berperan aktif di dalamnya, agar pebelajar dapat dengan mudah menguasai materi pembelajaran serta lebih mengedepankan prinsip pembelajaran bermakna yang lebih bersifat fungsional dan kontekstual. Proses pembelajaran yang hanya menstransfer pengetahuan tidak memberikan peluang kepada pebelajar untuk berinteraksi dan bertransaksi antar pebelajar. Artinya proses pembelajaran dirancang agar mampu mengaktifkan pebelajar, mengembangkan kreativitas dan mampu memberikan pebelajar keterampilan, pengetahuan dan sikap untuk hidup.

Sejalan dengan pemikiran di atas Shambaugh \& Magliaro (2006) menuliskan lima tema utama belajar. Kelima konsep belajar tersebut adalah (1) organizing knowledge in memory, (2) solving problems, (3) developing learners, (4) learning how to learn, dan (5) living and learning in the world. Konsep-konsep belajar tersebut diperlukan untuk membelajarkan pebelajar menghadapi abad belajar. Lebih lanjut Sigler \& Saam, (2007).

Konsekwensi dari adanya perubahan paradigma pembelajaran seperti yang telah dipaparkan di atas memerlukan adanya kemampuan untuk memilih dan penerapan strategi pembelajaran yang lebih inovatif, guna memberi peluang kepada para pebelajar untuk menumbuh kembangkan berbagai potensi yang dimiliki. Banyak strategi yang dapat dipilih dan diterapkan, agar proses pembelajaran bisa berjalan optimal. Dalam kontek ini strategi pembelajaran diacukan sebagai penataan cara-cara yang dapat digunakan dalam kondisi tertentu sehingga terwujud suatu urutan langkah-langkah prosedural yang dapat dipakai untuk mencapai hasil yang diinginkan. Para dosen dan para guru menyadari bahwa penggunaan strategi pembelajaran yang tidak tepat, tidak melibatkan mahasiswa secara aktif, bersifat monoton akan berpengaruh terhadap perolehan belajarnya pada mata kuliah yang dipelajari. Rendahnya hasil belajar mahasiswa dapat berimplikasi pada menurunnya kualitas lulusan dalam menguasai kompetensi mata kuliah yang seharusnya dikuasai.

Pembelajaran berbasis Masalah (PBL) adalah merupakan strategi pembelajaran dimana pebelajar dapat belajar memecahkan masalah secara kolaboratif untuk dapat merefleksikan pengalaman belajarnya. Adapun karakteristik PBL adalah: (1) belajar dikendalikan oleh tantangan, open-ended problems, (2) pebelajar bekerja dalam kelompok kolaboratif kecil, dan (3) pembelajar berperan sebagai fasilitator belajar. Secara keseluruhan PBL adalah strategi yang efektif untuk meningkatkan keterampilan pemecahan masalah dalam setiap pembelajarannya. Pembelajaran harus dirancang dalam suatu kondisi yang 
menyenangkan sehingga pebelajar akan termotivasi dari awal sampai akhir pembelajaran. Dalam penelitian ini PBL merupakan salah satu alternatif yang dapat digunakan untuk memperbaiki dan meningkatkan kualitas pembelajaran.

Merujuk uraian di atas penelitian ini dimaksudkan untuk mengkaji penerapan strategi pembelajaran "Problem Based Learning" sebagai upaya dalam meningkatkan aktivitas pembelajaran dan perolehan belajar mahasiswa PPKn angkatan 2018. Dalam penelitian ini mata kuliah yang dipilih adalah mata kuliah Strategi Pembelajaran PPKn. Pertimbangan yang mendasari pemilihan mata kuliah ini adalah (1) sebagian besar pokok bahasan mata kuliah Strategi Pembelajaran PPKn dapat diajarkan dengan strategi pembelajaran Problem-Based Learning (PBL), (2) mata kuliah ini diampu sendiri oleh peneliti, sehingga permasalahan dalam mata kuliah ini mudah diketahui, dan (3) permasalahan yang berkenaan dengan mata kuliah ini cukup banyak ditemukan di lapangan, sehingga perlu dicarikan solusi pemecahan secara tepat.

Mengacu pada paparan latar belakang masalah di atas, rumusan masalah dalam penelitian ini adalah sebagai berikut:

1. Bagaimanakah aktivitas perkuliahan mahasiswa angkatan 2018 PPKn Angkatan 2018 pada mata kuliah Strategi Pembelajaran PPKn.?

2. Apakah penggunaan Strategi Pembelajaran PPKn PBL dapat memperbaiki hasil belajar mahasiswa angkatan 2018 PPKn pada mata kuliah Strategi Pembelajaran PPKn.?

\section{STUDI LITERATUR}

Kensepsi mengenai strategi pembelajaran berbasis masalah (PBL) pada awalnya dikembangkan di Mc.Master University, Hamilton, Ontario, Kanada pada akhir tahun 1960 an. PBL diciptakan sebagai panduan filosofis untuk pengembangan sekolah kedokteran baru. Dalam Wikipedia dikemukakan bahwa PBL adalah strategi pembelajaran dimana para pebelajar memecahkan masalah secara kolaboratif dan merefleksi pengalaman mereka. Adapun karakteristik PBL: (1) belajar dikendalikan oleh tantangan, (2) pebelajar bekerja dalam kelompok kolaboratif dan (3) guru berperan sebagai fasilitator belajar. secara keseluruhan PBL adalah strategi yang efektif untuk meningkatkan keterampilan pemecahan masalah. Pebelajar diharapkan dapat mengkonstruksi sendiri pengetahuan nya yang bersumber dari fakta-fakta yang mereka kumpulkan melalui serangkaian pengkajian masalah dan situasi kontekstual kekinian. Melalui kerja kelompok pebelajar akan dapat mencapai tingkat pemahaman yang lebih tinggi serta membentuk pengetahuan dan keterampilan. Ide dasar dari prinsip PBL adalah belajar diawali dengan sebuah masalah, kemudian pebelajar diharapkan untuk memecahkannya melalui proses diskusi dan kerja kelompok..

Karakteristik PBL tentu sangat berbeda dengan karakteristik strategi pembelajaran yang berpusat pada guru sebagai mana yang sudah lazim dilaksanakan di sekolah, implentasi strategi PBL memerlukan persiapan yang matang bagi guru utamanya dalam menyiapkan sejumlah masalah untuk selanjutnya dipecahkan secara bersama-sama dalam kelas maupun di luar kelas. Dalam pelaksanaan nya pebelajar dituntut untuk bekerja atau belajar dalam kelompok kecil dengan suasana santai dan menyenangkan, berbagi pengetahuan dan bekerja sama, saling menolong antara pebelajar satu dengan lainnya dalam membangun pemahaman dengan mengaplikasikan apa yang mereka telah pelajari untuk suatu kasus dan masalah yang telah disiapkan oleh guru ataupun pebelajar menemukan sendiri atau bersama-sama. Pembelajar atau dosen berperan menjadi fasilitator, mengarahkan dan membantu memberikan menjelasan.

Dengan demikian sebagai sebuah strategi pembelajaran PBL memiliki kelebihan 1) Dengan PBL akan terjadi pembelajaran bermakna. Belajar dapat semakin bermakna dan dapat diperluas ketika pebelajar berhadapan dengan situasi yang 
bersifat kontekstual. 2) Dalam PBL pebelajar mengintegrasikan pengetahuan dan ke trampilan secara simultan dan menga plikasikannya dalam konteks yang relevan 3) PBL dapat meningkatkan kemampuan berpikir kritis, menumbuhkan inisiatif, dalam bekerja serta dapat mengembangkan hubungan interpersonal dalam bekerja kelompok.

Syntak atau langkah-langkah strategi pembelajaran PBL meliputi beberapa langkah 1) Konsep Dasar, memberikan konsep dasar, petunjuk, referensi yang diperlukan dalam pembelajaran. 2). Pendefinisian Masalah, fasilitator menyampaikan skenario atau permasalahan kemudian pebelajar melakukan berbagai kegiatan dimana anggota kelompok mengungkapkan pendapat, ide, dan tanggapan terhadap masalah secara bebas dalam situasi belajar yang santai dan menyenangkan untk memunculkan atau menemukan alternatif pemecahan. 3). Pembelajaran Mandiri, pebelajar mencari berbagai sumber belajar yang relevan untuk dapat memperjelas isu atau masalah yang akan dipecahkan. 4)Pertukaran Pengetahuan, setelah mendapatkan sumber untuk keperluan pendalaman materi dalam langkah pembelajaran mandiri 5)Penilaian, penilaian dilakukan dengan memadukan tiga aspek pengetahuan, kecakapan dan sikap (Dikbud, 2013). PBL sangat menghargai keberadaan dan perbedaan individu.

Setiap individu diharapkan untuk terlibat aktif dan memegang peranan penting dalam kegiatan-kegiatan pemecahan masalah, baik secara kooperatif, maupun kolaboratif. Arends, mengemukakan bahwa proses belajar berbasis masalah secara umum meliputi tujuh langkah yang digambarkan dalam.

Tabel. 1 Sintaks Strategi Problem Based Learning

\begin{tabular}{c|ll}
\hline Tahap & $\begin{array}{l}\text { Prosedur } \\
\text { Pembelajaran }\end{array}$ & Kegiatan \\
\hline \multirow{2}{*}{1} & $\begin{array}{l}\text { Mengorientasi } \\
\text { pebelajar pada } \\
\text { masalah }\end{array}$ & $\begin{array}{l}\text { Dosen menjelaskan } \\
\text { tujuan } \\
\text { pembelajaran, } \\
\text { menjelaskan }\end{array}$ \\
\hline
\end{tabular}

\begin{tabular}{|c|c|c|}
\hline & & $\begin{array}{l}\text { logistik yang } \\
\text { diperlukan, dan } \\
\text { memotivasi } \\
\text { pebelajar agar } \\
\text { terlibat aktif dalam } \\
\text { aktivitas } \\
\text { pemecahan } \\
\text { masalah } \\
\end{array}$ \\
\hline 2 & $\begin{array}{l}\text { Mengorganisasi } \\
\text { pebelajar untuk } \\
\text { belajar }\end{array}$ & $\begin{array}{l}\text { Dosen membantu } \\
\text { pebelajar } \\
\text { mendefinisikan dan } \\
\text { mengorganisasikan } \\
\text { tugas-tugas belajar } \\
\text { yang berhubungan } \\
\text { dengan masalah }\end{array}$ \\
\hline 3 & $\begin{array}{l}\text { Membantu } \\
\text { penyelidikan } \\
\text { sendiri dan } \\
\text { kelompok }\end{array}$ & $\begin{array}{l}\text { Dosen mendorong } \\
\text { pebelajar untuk } \\
\text { mengumpulkan } \\
\text { informasi yang } \\
\text { sesuai, } \\
\text { melaksanakan } \\
\text { eksperimen, dan } \\
\text { mencari penjelasan } \\
\text { dan solusi } \\
\end{array}$ \\
\hline 4 & $\begin{array}{l}\text { Mengperolehankan } \\
\text { dan menyajikan } \\
\text { perolehan karya } \\
\text { dan memamerkan }\end{array}$ & $\begin{array}{l}\text { Dosen membantu } \\
\text { pebelajar dalam } \\
\text { merencanakan dan } \\
\text { menyiapkan } \\
\text { perolehan karya } \\
\text { yang sesuai seperti: } \\
\text { laporan, dan } \\
\text { membantu mereka } \\
\text { berbagi tugas } \\
\text { mereka dengan } \\
\text { yang lainnya }\end{array}$ \\
\hline 5 & $\begin{array}{l}\text { Menganalisis dan } \\
\text { mengevaluasi } \\
\text { proses pemecahan } \\
\text { masalah }\end{array}$ & $\begin{array}{l}\text { Dosen membantu } \\
\text { pebelajar untuk } \\
\text { merefleksi dan } \\
\text { mengadakan } \\
\text { evaluasi terhadap } \\
\text { penyelidikan dan } \\
\text { proses-proses } \\
\text { belajar yang } \\
\text { mereka pergunakan }\end{array}$ \\
\hline
\end{tabular}

Sumber: Arends, 2004

Merujuk dari uraian di atas penelitian ini dimaksudkan untuk mengkaji penerapan strategi pembelajaran "Problem Based Learning" sebagai upaya dalam meningkatkan aktivitas dan hasil belajar mahasiswa PPKN angkatan 2018. Dalam penelitian ini mata kuliah yang dipilih adalah mata kuliah Strategi Pembelajaran PPKn. 
Pertimbangan yang mendasari pemilihan mata kuliah ini adalah (1) sebagian besar pokok bahasan mata kuliah Strategi Pembelajaran dapat diajarkan dengan strategi pembelajaran Problem-Based Learning (PBL), (2) mata kuliah ini diampu sendiri oleh peneliti, sehingga permasalahan dalam mata kuliah ini mudah diketahui, dan (3) permasalahan-permasalahan yang berkenaan dengan mata kuliah ini cukup banyak ditemukan di lapangan, sehingga perlu dicarikan solusi pemecahan masalah yang tepat. Masalah masalah yang disajikan adalah masalah ditentukan oleh peneliti, diangkat dan disesuaikan dengan pokok bahasan yang ada dalam materi pembelajaran. Implementasi dari strategi pembelajaran PBL dimana pebelajar terlibatkan langsung secara aktif untuk memecahkan suatu permasalahan secara berkelompok, kemudian perolehan kerja kelompoknya dipresentasikan dalam kelas, sehingga terjadi suatu interaksi sosial yang baik sebagai mekanisme meningkatkan aktivitas dan perolehan belajar, atinya bahwa gagasan dan ide ide maupun prakarsa yang muncul dalam belajar lebih didominasi oleh pebelajar.

\section{METODE PENELTIAN}

Jenis penelitian ini adalah jenis penelitian tindakan kelas (Class Action Research) yaitu suatu penelitian yang dikembangkan bersama sama dengan memanipulasi variable untuk melakukan perbaikan terhadap proses pembelajaran di kelas. Di samping itu penelitian ini merupakan suatu kajian yang bersifat reflektif tentang keadaan, peristiwa maupun kejadian secara alami di kelas khususnya yang berkaitan dengan aktivitas pem belajaran mahasiswa PPKn angkatan 2018 serta perolehan belajar nya selama proses pembelajaran berlangsung pada mata kuliah Strategi Pembelajaran. Pendekatan pe nelitian ini menggunakan pendekatan deskriptif kualitatif. Rancangan atau pola pelaksanaan penelitian ini menggunakan pola dua sillus yakni siklus I dan siklus II. Adapun gambar siklus 1 dan siklus 2 disajikan seperti pada Gambar 1 di bawah ini:

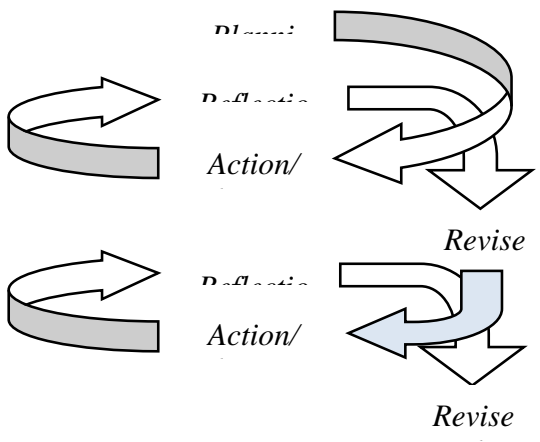

Gambar 1: Spiral Penelitian Tindakan Kelas (adaptasi dari Hopkins, 1993)

\subsection{Tempat dan Waktu Penelitian}

Penelitian ini dilakukan di Kampus Universitas Adi Buana Surabaya pada Program Studi PPKn. Penetapan prodi PPKn disebabkan peneliti adalah dosen prodi PPKn sekaligus sebagai implementasi pelaksanaan program hibah penugasan dosen di sekolah (PDS) pada semester ganjil tahun 2019.

\subsection{Subjek Penelitian}

Subjek penelitian ini adalah mahasiswa program studi PPKn angkatan 2018 pada semester ganjil tahun ajaran 2019/2020 dengan jumlah 29 orang mahasiswa. Penetapan subyek menggunakan cluster artinya ditentukan berdasarkan kelas dengan seluruh mahasiswa yang menempuh mata kuliah Strategi Pembelajaran sebagai obyek penelitiannya.

\subsection{Instrumen Penelitian}

Penelitian ini menggunakan dua jenis instrumen yaitu: pertama adalah Lembar observasi yang digunakan untuk memproleh data mengenai aktivitas mahasiswa dalam pembelajaran mata kuliah Strategi Pembelajaran PPKn pada mahasiswa angkatan 2018. Kedua Tes, Intrumen tes 
yang dimaksud dalam penelitian ini adalah tes hasil belajar pada ranah kognitif, bentuk nya adalah test yang brsifat uraian, tes disusun oleh penelti. Tes dilaksanakan pada siklus I maupun siklus II.

\subsection{Prosedur Penelitian}

Rancangan atau pola pelaksanaan penelitian ini menggunakan pola dua siklus yakni siklus I dan siklus II, proses dan tahapan penelitian pada masing-masing siklus adalah sama terdiri dari 4 tahap yaitu tahap perencanaan tindakan, tahap pelaksanaan tindakan, tahap observasi, dan tahap refleksi. Namun pada siklus II perencanaan tindakan dilakukan berdasarkan hasil refleksi pada siklus I.

\subsection{Teknik Pengumpulan Data}

Teknik pengumpulan data pada penelitian ini dilakukan dengan dua cara yaitu melalui pengamatan atau observasi. Pengamatan ini dilakukan terhadap akativitas mahasiswa PPKn angkatan 2018 pada setiap proses peerkuliahan mata kuliah Strategi Pembelajaran PPKn dengan menggunakan strategi PBL. Kedua melakukan tes, tes yang dimaksudkan dalam kontek ini adalah untuk mengukur perolehan belajar mahasiswa PPKn angkatan 2018.

\subsection{Teknik Analisis Data}

Teknik analisis data yang digunakan untuk menganalisis data yang bersifat kualitatif dan kuantitatif. Adalah teknik analisis deskriptif kualitatif dengan menggunakan rumus persentase.
Tabel. 2 Data Aktifitas Belajar Mahasiswa Angkatan 2018 Pada Siklus 1

\begin{tabular}{|c|c|c|c|}
\hline \multirow[t]{2}{*}{ No } & \multirow[t]{2}{*}{ Indikater. } & \multicolumn{2}{|c|}{ Kategori } \\
\hline & & $\begin{array}{l}\text { Taraf } \\
\text { Keberbasilan }\end{array}$ & $\begin{array}{l}\text { Nilai } \\
\text { (huruf) }\end{array}$ \\
\hline 1 & $\begin{array}{l}\text { Mendengarkan penielasan } \\
\text { dosen }\end{array}$ & Cukue & C \\
\hline 2 & Bertanya kepada dosen & Cukne. & C \\
\hline 3 & Menjamab pertanyan dosen & Baik & B \\
\hline 4 & Aktritas Diskusi & Baik & B \\
\hline 5 & $\begin{array}{l}\text { Mendengarkan sajaan } \\
\text { presentasi }\end{array}$ & Baik & B \\
\hline 6 & Mengemukakan pendapat & Cuku? & $\mathrm{C}$ \\
\hline 7 & $\begin{array}{l}\text { Mengajukan } \\
\text { pertanyaan,sanggahan }\end{array}$ & Kurang & $\mathrm{K}$ \\
\hline 8 & Bekeria sama & Cukup & $\mathrm{C}$ \\
\hline 9 & Laporan Kelompok & Baik & B \\
\hline 10 & Sikap Dalam berdiskusi & Baik & B \\
\hline
\end{tabular}

$$
\text { Keberhasilan tindakan pengajaran }=\frac{\sum \text { Indikatorkegiatan yang muncul }}{\sum \text { Seluruh indikator }} X 100 \%
$$

\section{HASIL DAN PEMBAHASAN}

\subsection{Hasil}

Data mengenai aktivitas belajar ahasiswa yang diperoleh dengan menggunakan instrument lembar pengamatan diolah menggunakan teknik analisis deskriptif kualitatif, berdasarkan perhitungan hasil analisis menunjukkan sebagai berikut:

Tabel 2 di atas menunjukkan pada siklus I aktivitas pembelajaran seperti: mende ngarkan penjelasan dosen, menjawab pertanyaan dosen, aktivitas mahasiswa selama diskusi, mendengarkan sajian presentasi, laporan kelompok, sikap dalam berdiskusi termasuk katagori baik. sedangkan mengemukakan pendapat, bekerja sama, mendengarkan penjelasan dosen, bertanya kepada dosen termasuk katagori cukup. Sedangkan mengajukan pertanyaan maupun sanggahan termasuk katagori kurang. 
Tabel. 3 Data Aktifitas Belajar Mahasiswa Angkatan 2018 Pada Siklus II

\begin{tabular}{|l|l|l|l|}
\multirow{2}{*}{ No } & Indikator & \multicolumn{2}{|c|}{ Kategori } \\
\cline { 3 - 4 } & & $\begin{array}{l}\text { Taraf } \\
\text { Keberhasilan }\end{array}$ & $\begin{array}{l}\text { Nilai } \\
\text { (huruf) }\end{array}$ \\
\hline 1 & $\begin{array}{l}\text { Mendengarkan penjelasan } \\
\text { dosen }\end{array}$ & Baik & B \\
\hline 2 & Bertanva kepada dosen & Baik & B \\
\hline 3 & Menjawab pertanyaan dosen & Baik & B \\
\hline 4 & Aktivitas Diskusi & Sangat Baik & A \\
\hline 5 & $\begin{array}{l}\text { Mendengarkan sajian } \\
\text { presentasi }\end{array}$ & Baik & B \\
\hline 6 & Mengemukakan pendanat & Baik & B \\
\hline 7 & $\begin{array}{l}\text { Mengajukan } \\
\text { pertanyaan.sanggahan }\end{array}$ & Baik & B \\
\hline 8 & Bekeria sama & Baik & B \\
\hline 9 & Laporan Kelompok & Baik & B \\
\hline 10 & Sikan Dalam berdiskusi & Sangat Baik & A \\
\hline
\end{tabular}

Tabel di atas menunjukkan bahwa pada siklus II aktivitas pembelajaran seperti aktivitas diskusi dan sikap dalam berdiskusi termasuk katagori sangat baik, sedangkan mendengarkan penjelasan dosen bertanya kepada dosen menjawab pertanyaan dosen, mendengarkan sajian presentasi, menga jukan pertanyaan dan sanggahan serta pembuatan laporan kelompok termasuk dalam katagori baik, Sedangkan bekerja sama dan mengemukakan pendapat termasuk katagori cukup.

Mengenai perolehan belajar pada siklus I dan II menunjukkan adanya perubahan yang sangan signifikan artinya ada kenaikan sebesar $20,7 \%$ bila dibandingkan pada siklus I. Secara lebih rinci perolehan hasil belajar pada siklus I dan II disajikan pada table di bawah ini.

Tabel. 4 Tingkat Ketuntasan Belajar Pada Siklus I dan II

\begin{tabular}{|l|l|l|l|l|}
\hline No & Siklus & $\begin{array}{l}\text { Tingkat di atas } \\
\text { KKM }\end{array}$ & $\begin{array}{l}\text { Tingkat di bawah } \\
\text { KKM }\end{array}$ & Imlh \\
\hline 1 & Siklus I & $69 \%$ & $31,0 \%$ & 12 \\
\hline 2 & Siklus II & $89,7 \%$ & $10,0 \%$ & 3 \\
\hline
\end{tabular}

Data pada tabel di atas menunjukkan perolehan belajar pada siklus I dari 29 mahasiswa, hanya 20 mahasiswa atau sebesar $69,0 \%$ mencapai ketuntasan belajar sedangkan 9 orang atau sebesar $31 \%$ belum mencapai ketuntasan belajar. Sedangkan pada siklus II dari 29 mahasiswa sebayak 26 orang atau sebesar $89,7 \%$ mencapai ketuntasan belajar, sedangkan 3 mahasiswa atau sebesar $10,3 \%$ belum mencapai ketuntasan belajar.

\subsection{PEMBAHASAN}

Penerapan strategi PBL selama penelitian dapat dikatakan berjalan dengan baik. Temuan penelitian menunjukkan bahwa penerapan model PBL dalam meningkatkan aktivitas belajar mahasiswa menunjukkan peningkatan yang signifikan, artinya penggunaan strategi PBL di kelas membuat kelas semakin hidup, artinya interaksi dalam pembelajaran menjadi lebih baik. Demikian juga dengan perolehan belajar mahasiswa mengalami peningkatan yang cukup signifikan. Proses pembelajarannya yang diawali dengan menjelaskan tujuan pembelajaran, membentuk kelompok untuk belajar memecahkan masalah. Peneliti berperan sebagai pembelajar dengan dibantu seorang kolega yang berperan sebagai observer. Pada penelitian ini aktivitas belajar mahasiswa pengukurannya di dasarkan pada instrument pengamatan hasilnya menunjukkan sangat baik pada siklus I maupun siklus II menunjukkan peningkatan.

\section{A. Keterlaksanaan Strategi Pembelajaran Berbasis Masalah (PBL)}

Keterlaksanaan

Strategi pembelajaran berbasis masalah (PBL) pada proses pembelajaran mata kuliah Strategi Pembelajaran PPKn dapat terlaksana dengan baik, permasalahan yang dihadapi pada siklus I adalah mengenai keterbatasan alokasi waktu yang masih kurang sehingga berdampak pada tidak cukupnya waktu pada saat melakukan diskusi, kemudian nampak yang paling dominan dalam menjawab maupun bertanya cenderung mahasiswa yang pandai. Perbaikan tindakan yang dilakukan pada siklus II yaitu: pengaturan alokasi waktu dalam setiap tahap pembelajaran diperhatikan sesuai dengan skenario dalam satuan acara perkuliahan (SAP) sehingga mahasiswa cukup waktu 
untuk melakukan diskusi. Hasil penelitian ini menunujukkan bahwa strategi pembelajaran berbasis masalah (PBL) dapat meningkatkan aktivitas belajar ditandai dengan meningkatnya aktifitas mahasiswa dalam berdiskusi. Penjelasan di atas me nunjukkan bahwa untuk meningkat kan aktivitas belajar mahasiswa diperlukan suatu strategi tertentu dari dosen, dosen dituntut mampu memilih strategi pembelajaran yang sesuai dengan karak teristik materi pembelajaran. Melalui pemilihan dan penerapan strategi yang sesuai akan berdampak pada meningkatnya kualitas pembelajaran itu sendiri.

\section{KESIMPULAN}

Berdasarkan analisis analisis dan pembahasan dapat ditarik simpulan penelitian sebagai berikut

1. Melalui Strategi Pembelajaran PBL pembelajaran mata kuliah Strategi Pembelajaran PPKn dapat mening katkan aktivitas belajar mahasiswa PPKn angkatan 2018 pada mata kuliah Strategi Pembelajaran.

2. Melalui penerapan Strategi Pem belajaran PBL dalam pembelajaran dapat meningkatkan perolehan belajar maha siswa PPKn angkatan 2018 pada mata kuliah Strategi Pembelajaran.

\section{REFERENSI}

Arends. 2004. Belajar dan Pembelajaran, Rineka Cipta, Jakarta,

Franz, D. P, Hopper, P. F., \& Kritsonis, W. A. 2007. National impact: Creating teacher leaders through the use of problem-based learning. National Forum of Applied Educational Research Journal, 20(3): 1-9.

Franz, D. P, Hopper, P. F., \& Kritsonis, W. A. 2007. National impact: Creating teacher leaders through the use of problem-based learning. National Forum of Applied Educational Research Journal, 20(3): 1-9.

David Hopkins. 1993. A Teacher's Guide to Classroom Research. Philadelphia. Open University Press
Raharso, S. 2007. Implementasi problembased learning di perdosenan tinggi. Ilmu Pendidikan, 34(1): 55-61.

Sadia, I W. \& Suma, K. 2006. Pengembangan kemampuan berpikir formal siswa di kabupaten Buleleng melalui penerapan model pembelajaran "learning cycle" dan "problem based learning" dalam pelajaran fisika. Laporan penelitian tidak diterbitkan. Singaraja: Universitas Pendidikan Ganesha Singaraja.

Sasmedi, D., Rahman, A., Zaidin, H., dan Asriyanti, E. 2005. Improving the students' ability to speak english using pictures through problem based learning model. Jurnal Ilmu Kependidikan, 2(3): 233-252.

Sigler, E. A., \& Saam, J. 2006. Teacher candidates conceptual understanding of conceptual learning: From theory to practice. Journal of Scholarship of Teaching and Learning, 6, 118-126.

Thalib, A., Mardin, Alam, S., dan Tibarang, K. 2005. Peningkatan hasil belajar matematika melalui penerapan model pembelajaran berbasis masalah pada siswa SMP. Jurnal Ilmu Kependidikan, 2(3): 253-266.

Wikipedia. 2008. Problem-based learning. (Online),

(http://en.wikipedia.org/wiki/Problembasedlearning\#Presentingproblems to learners, diakses 10 April 2008).

McTaggart, R. 1995. Action research: a short modern history. Victoria: Deakin University Press.

Woods, D. R. 2006. Preparing for pbl. Third edition. Hamilton: McMaster University. 